\title{
Local Wisdom-based Dance Learning: Teaching Characters to Children through Movements
}

\author{
Dedi Rosala $^{\varpi 1}$, Agus Budiman² \\ 1,2 Dance Education Department, Universitas Pendidikan Indonesia, Bandung, Indonesia \\ $\bowtie$ dedirosala1957@gmail.com
}

\begin{abstract}
The character education implementation in every school becomes a program of national education system policy in Indonesia. Its orientation is more focused on advancing national character development based on local wisdom and unique culture in Indonesia. The authority of the Indonesian education system policy program in strengthening character education covers religiousness, nationalism, independency, mutual cooperation, and integrity with the development of local wisdom-based learning materials. The purpose of this research is to discover the process of dance learning implementation in students' character education development. This research employs quantitative with descriptive statistics data analysis. The data were collected through an observation of 22 primary school students during a dance learning process and in-depth interviews to two dance teachers to obtain data regarding local wisdom-based dance learning implementation to develop students' characters. The findings show that character education developed in local wisdom-based dance learning can be done through various learning activities such as appreciation and introduction of traditional dance materials, instilling values, independent and group study to build independency and mutual cooperation, and familiarize students to pray before and after learning. These are to plant local wisdom values through dance movement learning.
\end{abstract}

Keywords: character education, dance learning, local wisdom values, traditional games, dance movement

How to Cite: Rosala, D., Budiman, A. (2020). Local Wisdom-based Dance Learning: Teaching Characters to Children through Movements. Mimbar Sekolah Dasar, 7(3), 304-326. doi: http://dx.doi.org/10.17509/mimbar-sd.v7i3.28185.

INTRODUCTION Local wisdom signifies a culture of people unique identity (Hilman \& Hendriawan, 2018; Komariah \& Asyahidda, 2019; Mungmachon, 2012). Local wisdom encompasses a set of knowledge and value of a people that is made to be a basis of policy that people take to respond to the influence of outside culture (Dahliani, 2010; Suarmika \& Syarifah, 2019; Widesma \& Adnan, 2019). Local wisdom is one of local culture products (Kartikawangi, 2017; Sopa, 2018; Tresnawati, 2018; Sungkharat et al., 2010).

Moreover, local cultures need to be considered to exist in school education (Enyedy \& Goldberg, 2004; Hammond \& Brandt, 2004). In this case, local cultures and education have a close relationship to shape students behavior as the result of the education that has been implemented (Cherng et al., 2019; Hongcheng \& Minhui, 2010). In addition, local cultures can exist to develop teaching materials given in schools (Ho, 2006, 2016; Lo, 2014). Furthermore, local cultures even have become a part of education policy of a country (Hedegaard-Soerensen \& Grumloese, 2020). 
Dedi Rosala \& Agus Budiman, Local Wisdom-based Dance Learning: Teaching Characters...

In a further development, local cultures are often used as a basis of the development of character education implementation towards students. The concept of character education is frequently used to create the best education that has psychological functions in its implementation (Abu et al., 2015; Carr \& Harrison, 2015; Cunningham, 2007; Demirel et al., 2016; Lapsley \& Power, 2005; Niemiec, 2017). Moreover, the implementation of character education concept is always linked to moral education in school (Lapsley \& Power, 2005; Marvasti, 2004; Narvaez et al., 2006; Thornberg, 2010). In this context, character education is always connected to ethical education (Damm, 2011; Fadrusiana \& Triastuti, 2020; Sukendar et al., 2019). Furthermore, character education has been made a policy of national education system in a country (Alexander, 2003, 2005; van Oord, 2013) including in Indonesia.

Several researches have applied the concept local wisdom in education (Atmojo, 2015; Hidayah \& Ramli, 2017; Ilhami et al., 2019). The learning process tends to aim at building students' characters through values that exist in the local wisdom of a particular local area (Murwaningsih et al., 2020; Suastra et al., 2017; Sugiyo \& Purwastuti, 2017). The learning materials given lean heavily on local wisdom values attached of a particular people, which will be taught to students through a learning process that is carried out (Hasanah et al., 2016; Mubiar et al., 2020). In addition, another research talks about character education in primary schools learning activities (Ani, 2014; Kristanto, 2014; Sunaengsih, 2015).

Recently, character education is implemented in local wisdom-based dance learning as the core of the teaching materials development. In this case, the concept of implementing character education in a dance class can be seen from two different terminology perspectives that have different meanings, which is dance terminology and character education. Dance is a representation of time and space movement (Butterworth, 2004). Learning about dancing in schools is one of many self-expression activities that a student can do (Carr, 1984). Character is a universal value of human behaviors that covers all of life activities, whether it is related to God, oneself, another human being, or environment that is materialized inside the mind, through behavior, feeling, word, and action, which is based on norms of religion, law, manners, and customs (Suryadi, 2013; Wijanarko, 2019). In a simpler definition, character education is a process of educating individuals, which focuses more on moral education (Althof \& Berkowitz, 2006; Arthur, 2003; Revell \& Arthur, 2007).

A strong character of a nation will be influenced also by a generation of a nation that has strong characters (Baptiste, 2009). This ideology becomes the basis of education system policy in Indonesia to build a generation of the nation with a strong character. The statement is in line with the 2013 Curriculum stating that the development of character education is the basis of learning competencies achievement. The area of character education has become 
a goal of the 2013 Curriculum policy, which is depicted clearly in the competency standard for graduates that is restated in the core and basic competency. A character-based education has become one of the strengths emphasized in the 2013 Curriculum. However, in the realization process, there are many teachers that find difficulties in implementing the education system to achieve the desired learning purposes in the 2013 Curriculum.

The development of character education, as stated heavily in the 2013 Curriculum, focuses more on improving the students' attitude and personality. In this case, character education is understood as a means of helping students shape their characters optimally. Character education is in a direction to emphasize certain values such as respect, responsibility, honesty, care, and fairness. It also helps students to understand, pay attention to, and implement those values in daily life. Under the circumstances, schools are demanded to play their role and show their responsibility to teach and develop good values. Dance subject in the cultural arts and crafts is related to character values that are needed to develop and is related to the context of daily life.

Dance learning in schools is a subject that has a function to provide esthetical, ethical, and philosophical basics to students. Thinking sensitivity, imagination, and the realization of a creative mind is developed more by the potential of motoric sensor to catch the stimulants from the environment. The tendency of learning process that shows up is students play, imitate, and respond better to objects or activities, which are processed by their potential senses. The opportunity to discover creative behaviors from students will occur more from learning sources that come from each student's ability. In this case, Murgianto (1983) states that the value of dancing in the world of education does not lie only in the practice to master the skills and abilities but also in the possibility to develop the kids ability to express themselves.

Dancing has to give creative experience to kids and has to be taught as one of many ways to experience and restate the aesthetic value that happens in their life. Teaching materials or sources that are relevant with the age of primary school students basically has to be able to dig the children's world itself. For example, a child loves stories about animals, games, kid songs, and other materials that are related to the children's world.

Dance learning in schools does not lead kids to be an expert in dancing (Brown, 2014; Giguere, 2015; Koff, 2000). Through body movements, students are taught to explore their body potentials as an aesthetic source of dancing (Arkin, 1994; Gard, 2001). Therefore, it is important for teachers to understand pedagogy to teach dancing to students in schools (Biasutti, 2013; Connell, 2009; Cuellar-Moreno, 2016). In the recent era of technology, students are able to learn how to dance through technological devices such as a computer, mobile phone, and laptop (Boettcher, 1983; Politis, 1990). In the $21^{\text {st }}$ century era teachers are 
Dedi Rosala \& Agus Budiman, Local Wisdom-based Dance Learning: Teaching Characters...

demanded to have a whole and thorough competency of their duty and role as a dance teacher in schools (Andrzejewski, 2009; Gilbert, 2005; Sööł \& Viskus, 2014).

A research about dancing results in a philosophy that is based on a fundamental belief of artistic and aesthetic capacity of general human behaviors and of expressed values has shown through creative activities in the field of arts. Moreover, the philosophy can be made as a theoretical basis that can help finding things that are beneficial and have clear contribution to the development of science. An example of the formulation is the insistence on dancing that is experienced as a proper medium to express oneself. Therefore, if the movement of the intellectual, emotional, and spiritual realm is coordinated with the activities of body movement, then a dynamic life expression will emerge as a result (Margaret, 1985).

In a simpler definition, character education is a positive activity done by a teacher that has an impact towards the students' character being taught. Character education has become an educational movement that supports social, emotional, and ethical development of a student. It is also a proactive attempt done by schools or the government to help students develop their core of ethical and performance values such as empathy, honesty, diligence, fairness, tenacity, fortitude, responsibility, and appreciating oneself and others (Hapsari, 2013; Hariyanto, Samani, 2012; Maarif, 2018; Puspita, 2015; Citra, 2012).

According to Fathorrahman \& Farida, 2018; Larson, 2004; and Muttaqin, Raharjo, \& Masturi, 2018, character education can be understood as a sincere effort to develop, encourage, and empower positive personality through exemplars, studies (history and biography of great thinkers and philosophers), and emulation practice (a maximum effort to manifest wisdoms of what is being observed and learned) (Hariyanto, 2012; Muttaqin, Raharjo, \& Masturi, 2018). Therefore, character education is a process of giving guidance to students so that they can be a human being as a whole that has characters in the dimension of heart, mind, body, and sense and intention. Character education can be defined as value, personality, moral, and behavior education to improve students' ability to make a good decision, maintain what is good, and manifest the goodness in real life wholeheartedly (Hariyanto, 2012). In the publication of curriculum center, it is stated that character education has a function to (1) develop basic potential so that a student can have a kind heart, good mind, and good behavior; (2) strengthen and build a multicultural nation; (3) improve civilization of the nation that is competitive in the global field.

Moreover, several values that shape character building that is a result of an empirical study of the curriculum center has been identified. Values that come from religion, Pancasila, culture, and the purpose of national education are: (1) religious, (2) honest, (3) tolerance, (4) discipline, (5) hard work, (6) creative, (7) independent, (8) democratic, (9) curiosity, (10) national spirit, (11) loving the homeland, (12) respecting achievements, (13) 
friendly/communicative, (14) loving peace, (15) love to read, (16) care for the environment, (17) care for the society and (18) responsible. Furthermore, in the implementation at the education unit, the curriculum center recommends that it is started from the essential, simple, and easy-to-do value that is in line with the condition of each school such as cleanliness, tidiness, comfort, discipline, and politeness (Hariyanto, 2012).

The importance of character development, given the state of nature's wealth that continues to be exploited that will be gone one day and cannot be renewed, then an early preparation to build a good character has to be carried out immediately (Megawangi, 2004; Silkyanti, 2019; Suryana, 2013). The quality of human resources that have good characters, high working spirit, and independence is the one that will bring success to the nation in the future. Such spirit of the nation's culture will never end. It even will become a blessing in the future. Wynne (1991, in Megawangi, 2004) explains that there are two definitions of character. First, a character is the way a person behaves. If a person is not being honest, cruel, or greedy, then the person is said to manifest a bad character. On the other hand, if a person is honest and loves to help, then the person is said to manifest a noble character. Both terms of a character are closely related to personality. Someone can be said as a person of character if his or her behavior is in accordance with the moral principle.

All in all, the purpose of this research is to obtain data and information about the development of character education of students through local wisdom-based dance education. Strong local cultures in education implementation in one of private primary school in Bandung becomes one of the reasons the authors to find data and information that is focused on the problems 1) Student learning activities in dance learning by applying local culture concepts in the learning activities; and 2) The concept and results of the application of local wisdom values in dance learning designed by the teacher in developing teaching materials, especially in developing student character education through movement.

\section{METHOD}

The method used in this research is quantitative approach with descriptive statistic data analysis technique. The data were obtained from observations and interviews with arts and cultures teachers to get data and information about local wisdom-based dance learning implemented in one of private primary school in Bandung, West Java, Indonesia, which has a vision of a learning program that involves local wisdom potential of local areas around. The culture of education is applied and adopted from local wisdom values of local areas around that area reflected in various educational activities such as in how to behave, communicate, socialize, and adapt to a culture. Moreover, the potential of the local wisdom is used as a medium to develop teaching materials for every particular field of studies at the 
Dedi Rosala \& Agus Budiman, Local Wisdom-based Dance Learning: Teaching Characters...

school including enhancing teaching materials of dance class. In addition, other than used as a medium to develop teaching materials, the local wisdoms are implemented in other activities such as how to behave, to communicate, or how students greet each other, students greet teachers, and teachers greet students. Those values are also implemented in dance education activities.

\section{Participants}

The research involved 22 students as the participants, which consist of 9 male students and 13 female students. Other than students that became the participants of the research, this research involved 3 arts and culture teachers. The involvement of the participants is required to see the learning process of how students get dancing teaching materials using localwisdom-based learning approach. As for the teachers, their involvement is to obtain data and information about the development of local-wisdom-based teaching materials and the dancing learning process done implemented local wisdom values from local areas around.

\section{Data Collection}

The research was conducted in three months starting from May until July of 2019. The data collection began with an initial observation to see the dancing learning condition before the research was started. Dancing learning was carried out for $2 \times 35$ minutes starting from 07.00-08.10. To obtain data about local wisdom-based dancing learning, an observation towards students and teachers was done during the class hour. Moreover, to obtain data and information about teaching materials given by teachers in the local wisdom-based dancing learning, an interview was conducted outside of the teaching hours.

Table 1. Student Respondents Data

\begin{tabular}{lll}
\hline Gender & Total & $\%$ \\
\hline Male & 9 & $41 \%$ \\
Female & 13 & $59 \%$ \\
Total & 22 & $100 \%$ \\
\hline
\end{tabular}

Table 2. Respondent Data for Cultural Arts Teachers

\begin{tabular}{lll}
\hline Area of Expertise & Total & $\%$ \\
\hline Dance Teacher & 1 & $50 \%$ \\
Art teacher & 1 & $50 \%$ \\
Total & 2 & $100 \%$ \\
\hline
\end{tabular}


From all student and teacher respondents, the observations were focused on the process of dance learning in instilling local wisdom values with the design of dance learning materials given to students. The observations were more focused on student learning activities based on character education, the ability of students to understand learning material, the process of student-teacher interaction, and the process of student-student interaction through teacher-directed learning. In addition, the data of this research were obtained from audio recordings of semi-structured interviews with arts and culture teachers to obtain the data on the basic development of local wisdom-based dance learning materials, the methods used by teachers in providing local wisdom-based teaching materials, the media used by teachers in learning, and the results of assessment of local wisdom-based dance learning in developing character education for students according to the target of character education development in the national education curriculum policy. The research questions are more focused on several problems including: 1) What things are needed to be considered in the development of local wisdom-based dance learning materials?; 2) What strategies do teachers use in applying local wisdom-based dance learning materials to develop student character education?; 3) What media do teachers use in providing the materials?; and 4) What aspects are the focus of the local wisdom-based dance learning assessment used to develop student character education? This interview was conducted for approximately 60 minutes for each respondent.

\section{Data Analysis}

Based on the data and information from observation and interview results, the authors made a discussion theme based on predetermined data coding and categorization referring to Sherman \& Webb (2018) to provide differences in the data and information that is obtained as a result of the findings of the research problems. The coding is formulated based on the focus of the research problems according to data from observations and semi-structured interviews to distinguish data from observations on student learning activities and data from interviews with teachers about the development of teaching materials and strategies implementation. Data validation was done by checking the completeness of the data, checking the identity of the data filler, creating tabulation of data, and distributing the data based on the data groups to be analyzed.

The inductive analysis approach was used to analyze data repeatedly to produce a result of data analysis based on the results of the interpretation process of data that had been selected, categorized, compared, and put together (McMillan \& Schumacher, 2010). The coding process in the analysis step was conducted to categorize data or information from the text or visual data results (images, photos, etc.) as a database of the research that was conducted (Creswell, 2014). 
Dedi Rosala \& Agus Budiman, Local Wisdom-based Dance Learning: Teaching Characters...

\section{RESULTS}

\section{Local Wisdom Values in Teaching Materials Used in Teaching Characters to Students}

In this research, the kaulinan barudak song was used as a source of material for the development of local wisdom-based dance learning materials. Kaulinan barudak is a type of Sundanese folk game based on local wisdom in the form of kakawihan barudak or children's songs. Kakawihan barudak is a literary work whose work is unknown (anonymous), categorized as an oral folklore, and is the largest unwritten source (Gloriani, 2013).

The dance learning material for the kaulinan song was more focused on cultivating the values contained in the lyrics and poetic elements of the song. This is because the lyrics and poetic elements of kaulinan barudak song contain noble values of Sundanese cultural identity in particular, which is full of educational values for children. In addition, the characteristics of the students are also being considered. Therefore, the dance learning material designed through the kaulinan barudak song is more intended for primary school students, in which the local wisdom values can be applied in children's everyday life.

Kaulinan barudak is usually played in groups (teamwork). Kaulinan barudak is a type of traditional children's game, which is a genre of folklore that is performed in the form of games (Saepudin \& Damayani, 2016). Therefore, there are positive values contained in kaulinan barudak. Indirectly, kaulinan barudak invites children to learn to think creatively, not to act individually, to socialize, take responsibility, accept their own weaknesses, and acknowledge the strengths of others. As a form of local cultural diversity and wealth, there are several types of kaulinan barudak songs that are used as a teaching material, such as the Oray-orayan song. The lyrics of the kaulian barudak Oray-orayan song, which is the learning material for local wisdom-based dance, are as follows.

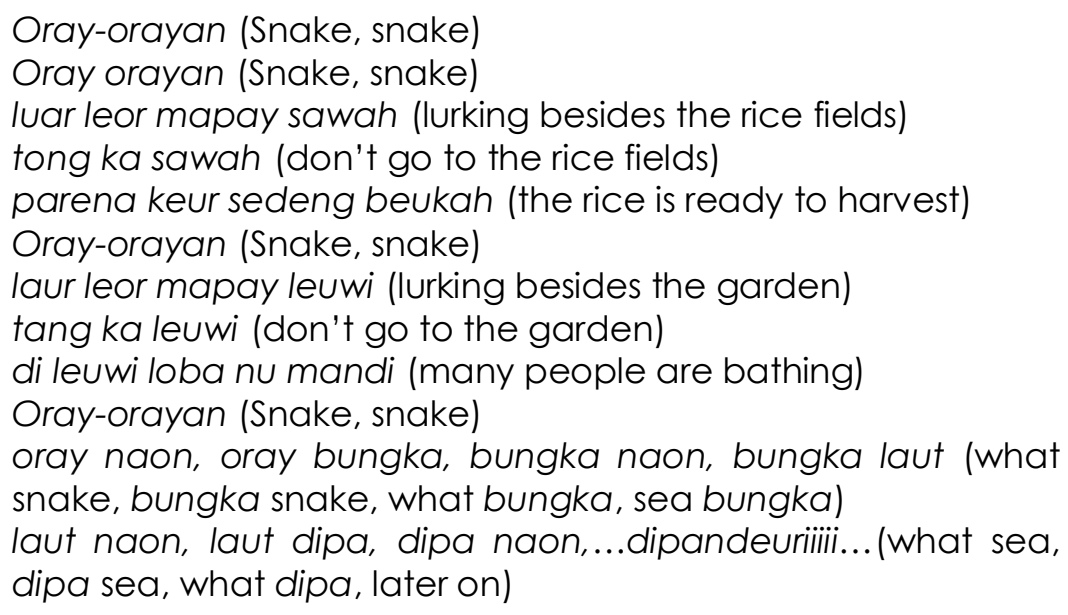

The Oray orayan song is one of the developed dance learning materials. It promotes children character education through local wisdom values that grow in the school area. The 
Iyrics of the Oray-orayan song have educational values. It teaches about the philosophy of a snake that it is able to avoid various dangers that can harm itself. This educational value can be observed from the circular movement of the snake, which is visualized by the way the game is played through teamwork, holding hands tightly so that it is not easy to let go when faced to danger (Lestari, 2017). In addition, the philosophy of the snake games teaches students about the character of teamwork and mutual cooperation.

\section{Local Wisdom Values in the Dance Learning Process to Teach Characters to Children}

Teaching characters to children with local wisdom-based dance learning was carried out in several learning stages. The local wisdom values in kaulinan barudak can be applied in dance learning as an attempt to improve children's attitudes or characters (Mulyati \& Hendriyana, 2013) Learning activities with kaulinan will help children to be involved in the learning that is being carried out more easily. This is because the games in kaulinan barudak are considered more fun and teach the meaning of sportsmanship in a game, especially the meaning of winning or losing in a game (Dermawan et al., 2020). Therefore, through traditional kaulinan games students' motivation in participating in dance lessons can be increased (Pratiwi, 2015).

\section{Praying before Learning}

A prayer activity is meant to educate children to get used to always remembering and carrying out all the obligations from the teachings of each student's religion, especially for Muslim children to always be obedient, pray, and stay away from all of the prohibitions. The essence of this religious value is the emphasis of early learning activities.

\section{Singing National Songs}

The activity of singing national songs is a mandatory stage for every subject given at school, including in dance class. The purpose of this learning activity is to instill the value of nationalism in children so that they always appreciate and respect the struggles of the heroes who participated in realizing the independence of Indonesia. Getting children used to singing national songs before learning is an attempt to instill nationalism values in children (Sari \& Utami, 2016; Sari, 2016).

\section{Reading, Understanding, and Presenting Kaulinan Barudak Song}

This stage was carried out at the beginning of the core learning activity before students are guided to interpret the kaulinan barudak song with the language of their body movements. During the learning activities, children were directed and guided to read and understand the meaning of each kaulinan barudak song, which was the material for dance learning at that time. Because there are meanings of local wisdom values in every sentence of kaulinan 
Dedi Rosala \& Agus Budiman, Local Wisdom-based Dance Learning: Teaching Characters...

barudak songs that are taught to children, understanding the values of local wisdom in the lyrics of kaulinan barudak song becomes one of the stages of teaching characters to children. At this learning stage, students were taught to be able to sing the kaulianan barudak song, which have been mastered by most children, especially primary school children in urban areas. This learning activity aims at building students' integrity to always know, appreciate, and have the motivation to learn about the richness of their culture.

\section{Exploring Kaulinan Song in Dance Movements}

Movement exploration is the main medium for dance learning. Students are directed to have the ability to exercise their bodies according to the learning theme given at that time. In this research, the process of exploring students' movements was further developed through the stimulus of the kaulinan barudak song entitled Oray-orayan. Initiating the movement exploration, the students' way of thinking was firstly constructed by re-understanding the meaning of the Oray-orayan song lyrics to be interpreted in the form of movements. In addition, students were conditioned to play the Oray-orayan game according to its original form. Then, at the next learning stage, students were taught to be able to process movements according to the Oray-orayan musical accompaniment pattern through rhythmic in the Oray-orayan kaulinan song. The form of movements developed in the learning activity explored more the forms of movements developed by students when during the learning activity. The exploration activity of the kaulinan barudak song can be directed as a stimulus to develop children's creative abilities (Kamilia et al., 2019).

\section{Presenting Learning Results in Front of Other Students}

This learning stage is important during the learning process to foster courageous attitudes and behaviors to be responsible for the learning outcomes. In addition, the activity of presenting their learning outcomes can teach students to be solid and work together in group learning activities. This stage also aims at educating students to always be disciplined and be able to work together with their friends. This stage always becomes a concern in dance learning activities at SD the school.

\section{Concluding Learning Outcomes}

This stage was carried out at the end to teach students to find their own conclusions from the learning activities. Concluding learning outcomes was always conducted in every meeting, especially at the end of the lesson so that students can understand the meaning of the learning activities. 


\section{Assessing Local Wisdom-based Dance Learning to Teach Characters to Students}

The dance learning refers to the 2013 Curriculum, where the teachers refer to the standardized contents set in the 2013 Curriculum, especially for cultural arts and crafts subject. However, in the implementation of the learning activity, schools gave authority to teachers to teach cultural arts and crafts according to their expertise and educational background. In accordance with the 2013 Curriculum, the material for cultural arts and crafts taught in schools consists of music, dance, and fine arts. Cultural arts and crafts subject had a different teacher for each subject, depending on the subjects being taught. Thus, learning the art of dance had relevant teaching staff with proper educational competences. However, in practice, it is regulated based on the school's decision.

This is an assessment of the overall students' competence in the area of character education values in dance learning shown during the learning process. The learning competencies to observe are the occurrence of religious, nationalist, independent, and cooperative attitudes improvement along with the results of the interviews. The five attitudinal competencies become observation area to be assessed through several assessment instruments used in the learning process activities carried out by students. The research assessment process was carried out in two parts, a pretest or an initial assessment and posttest at the end of the assessment.

The function of the initial assessment or pretest was to see the initial data on the behavior of students' attitudes before the learning activity is given. Meanwhile, the function of posttest is to observe significance changes in student attitudes after the learning activity is given. After the pretest assessment activities were carried out, the mean value $(x)$ of the pretest students is 70. The median (middle value) in the above pretest data is 75.5 , while the mode (values that often appeared) on the pretest values above are 75,76 , and 78 . The frequency table data is based on the data that has been obtained as follows.

Table 3. Distribution of Pretest Data Frequency of Learning Results based on Local Wisdom in Teaching Characters to Students

\begin{tabular}{lllll}
\hline No. & $\begin{array}{l}\text { Interval } \\
\text { Class }\end{array}$ & $\begin{array}{l}\text { Midpoi } \\
\mathbf{n t}\end{array}$ & Frequency & $\begin{array}{l}\text { Relative } \\
\text { Frequency }\end{array}$ \\
\hline 1. & $68.5-70.5$ & 71 & 4 & $18 \%$ \\
2. & $71.5-73.5$ & 74 & 3 & $14 \%$ \\
3. & $74.5-76.5$ & 77 & 8 & $36 \%$ \\
4. & $77.5-79.5$ & 80 & 5 & $23 \%$ \\
5. & $80.5-82.5$ & 83 & 1 & $4.5 \%$ \\
6. & $83.5-85.5$ & 86 & 1 & $4.5 \%$ \\
\hline
\end{tabular}


Dedi Rosala \& Agus Budiman, Local Wisdom-based Dance Learning: Teaching Characters...

Information:

1) The midpoint is the middle score of the interval class, which is taken from the upper class score plus 0.5 .

2) Frequency is the total number of students that were analyzed.

3) Relative frequency $=$ Frequency $/ \mathrm{n} \times 100 \%$.

From the data above, the results in a form of a percentage can be seen below:

1) There are 4 students who score between 68.5 - 70.5 or $18 \%$ of students.

2) There are 3 students who score between 71.5 - 73.5 or $14 \%$ of students.

3) There are 8 Students who score between $74.5-76.5$ or $36 \%$ of students.

4) There are 5 students who score between 77.5 - 79.5 or $23 \%$ of students.

5) There is one student who scores between $80.5-82.5$ or $4.5 \%$ of students.

6) There is one student who scores between 83.5 - 85.5 or $4.5 \%$ of students.

Thus, the results of the calculation of the data above can be illustrated in the graph below:

Students Score Graph

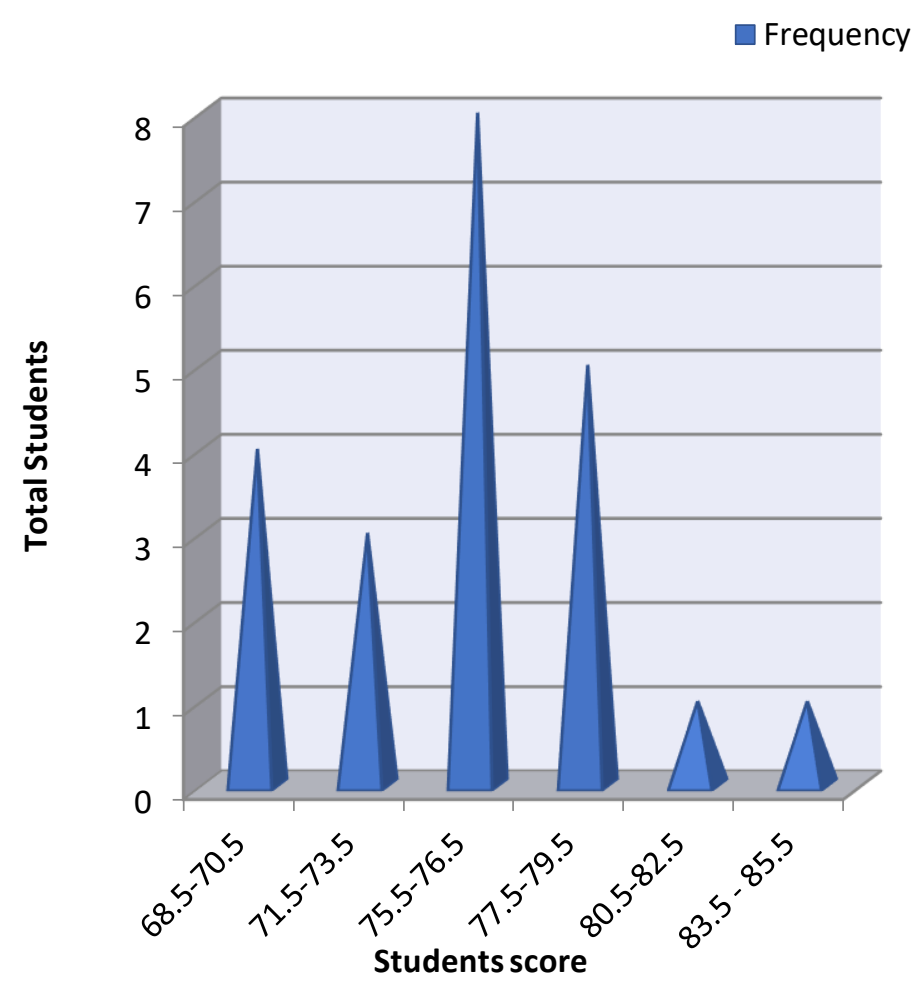

Graph 1. Pretest Score 
The graph above is a depiction of the pretest data result. There are four students who got a score of 68.5-70.5, three students who got a score of 71.5-73.5, eight students who got a score of 74.5-76.5, five students who got a score of 77.5-79, 5, one student who got a score of 80.5-82.5, and one student who got a score of 83.5-85.5.

In the data presentation section, the results obtained after local-wisdom-based dance learning activities were given to students to see the overall students' competence in the area of character education values in dance learning shown during the learning. The mean score $(\mathrm{x}$ ) of the students' pretest was 80 . The median (middle score) in the posttest data above was 81 , and the mode (values that often appear) on the posttest score above were 81,82 and 83 . The frequency table data is based on the data that has been obtained as follows.

Table 4. Distribution of Posttest Data Frequency of Learning Results based on Local Wisdom in Teaching Characters to Students

\begin{tabular}{lllll}
\hline No & $\begin{array}{l}\text { Interval } \\
\text { Class }\end{array}$ & $\begin{array}{l}\text { Midpoi } \\
\mathbf{n t}\end{array}$ & $\begin{array}{l}\text { Freque } \\
\text { ncy }\end{array}$ & $\begin{array}{l}\text { Relative } \\
\text { Frequency }\end{array}$ \\
\hline 1. & $68.5-70.5$ & 71 & 0 & $0 \%$ \\
2. & $71.5-73.5$ & 74 & 1 & $4.5 \%$ \\
3. & $74.5-76.5$ & 77 & 2 & $9 \%$ \\
4. & $77.5-79.5$ & 80 & 6 & $27.5 \%$ \\
5. & $80.5-82.5$ & 83 & 9 & $41 \%$ \\
6. & $83.5-85.5$ & 86 & 4 & $18 \%$ \\
\hline
\end{tabular}

Information:

1) The midpoint is the middle score of the interval class, which is taken from the upper class score plus 0.5 .

2) Frequency is the total number of students that were analyzed.

3) Relative frequency = Frequency / $\mathrm{n} \times 100 \%$.

From the data above, the results in a form of a percentage can be seen below:

There are 4 students who score between $68.5-70.5$ or $18 \%$ of students.

There is 0 student who scores between 71.5 - $73.50 \%$ of students.

There is 1 student who scores between $74.5-76.5$ or $4.5 \%$ of students. 
Dedi Rosala \& Agus Budiman, Local Wisdom-based Dance Learning: Teaching Characters...

There are 2 students who score between $77.5-79.5$ or $9 \%$ of students.

There are 9 students who score between 80.5 - 82.5 or $41 \%$ of students.

There are 4 students who score between 83.5 - 85.5 or $18 \%$ of students.

The data above is the result of data processing collected by the author at the end of the learning assessment. The data obtained from the teacher during assessment at the end of the session was expected to be able to show a depiction of the final condition of the students after participating in local-wisdom-based dance learning. Data and information obtained through posttest assessments to obtain information on the results of local wisdombased dance learning to teach characters to students will be given by the teachers. The assessment at the end of the session includes several aspects of assessing student learning outcomes related to cognitive, affective, and psychomotor competencies. Thus, the results of the data calculation above can be illustrated in the following graph:

\section{Students Score Graph}

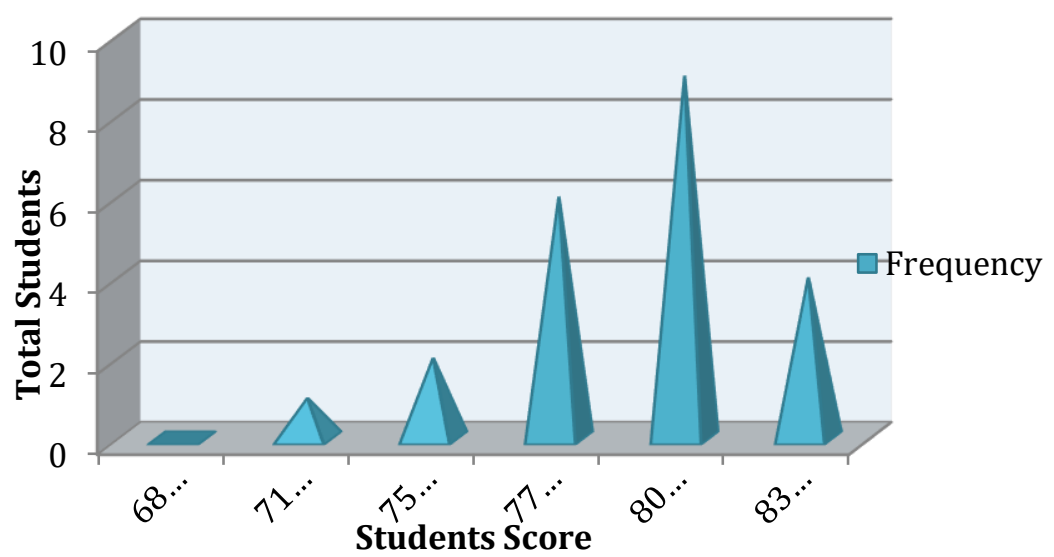

Graph 2. Posttest Score

The graphic above is a depiction of the posttest data result. There was no student who got a score of 68.5-70.5, one student who got a score of 71.5-73.5, two students who get a score of 74.5- 76.5, six students who got a score of 77.5-79.5, nine students who got a score of 80.582.5, and four students who got a score of 83.5-85.5. Based on the data above, it shows that after local wisdom-based dance learning, the character values of students in daily life shows a relatively good process of change. The real condition of this data was seen from the attitudes of students during learning, which show significant changes. When they sang the national songs, they began to show a serious and disciplined attitude as an attempt to appreciate the values of heroes and the nationalist spirit of students. Even when praying, the students showed a good attitude to fully appreciate the meaning of a prayer in all activities carried out by students. Another positive change was shown by the manifestation of 
independency, which was apparent from the willingness to study alone and with friends as a form of mutual cooperation and the value of integrity of the students. Moreover, among their friends, they always tried to help each other.

\section{CONCLUSIONS}

All in all, based on the data of the research result, it can be concluded that 1) local wisdombased dance learning can be implemented to primary school students to help them learn about characters; 2) the values of local cultural wisdom from the dance learning materials can be used as a stimulus to teach student characters; 3) fun learning strategies are more understandable and acceptable by students to help them comprehend and learn the materials given by teachers;4) the concept of character education for students through dance learning activities is very likely to be developed because in local wisdom-based dance learning materials, there are many character values that can be transmitted to students in the learning process; 5), character education in dance class is not only given by oral or theoretical delivery, but also is carried out through learning strategies that are able to condition students so that they can understand the meaning of the character education value implanted in the learning activities. In the future, this research can be used as an alternative dance learning model that can be applied by teachers in primary schools who teach dance, especially to educate teach characters to students through exploration of the kaulinan barudak game as a form of local wisdom values expressed through movement.

\section{ACKNOWLEDGMENT}

In this section, the authors would like to thank the chancellors, the faculty, and the Head of Dance Department who have given us the opportunity and confidence to conduct the research to find an innovation in dance learning, especially in teaching characters to primary school students through local wisdom-based dance learning.

\section{REFERENCES}

Abu, L., Mokhtar, M., Hassan, Z., \& Suhan, S. Z. (2015). How to develop character education of madrassa students in Indonesia. Journal of Education and Learning, 9(1), 79-86. http://dx.doi.org/10.11591/edulearn.v9i1.768

Alexander, H. A. (2003). Moral education and liberal democracy: Spirituality, community, and character in an open society. Educational Theory, 53(4), 367. https://doi.org/10.1111/j.1741-5446.2003.00367.x

Alexander, H. A. (2005). Education in ideology. Journal of Moral Education, 34(1), 1-18. https://doi.org/10.1080/03057240500049216 
Dedi Rosala \& Agus Budiman, Local Wisdom-based Dance Learning: Teaching Characters...

Althof, W., \& Berkowitz, M. W. (2006). Moral education and character education: Their relationship and roles in citizenship education. Journal of moral education, 35(4), 495518. https://doi.org/10.1080/03057240601012204

Andrzejewski, C. E. (2009). Toward a Model of Holistic Dance Teacher Education. Journal of Dance Education, 9(1), 17-26. https://doi.org/10.1080/15290824.2009.10387380

Ani, N. A. (2014). Pendidikan Karakter untuk Siswa SD dalam Perspektif Islam [Character Education for Elementary Students in an Islamic Perspective]. Mimbar Sekolah Dasar, 1(1), 50-58. doi: 10.17509/mimbar-sd.v1i1

Arkin, L. C. (1994). Dancing the Body: Women and Dance Performance. Journal of Physical Education, Recreation \& Dance, 65(2), 36-43. doi: 10.1080/07303084.1994.10606853

Atmojo, S. E. (2015). Learning which oriented on local wisdom to grow a positive appreciation of batik jumputan (ikat celup method). Jurnal Pendidikan IPA Indonesia, 4(1), 48-55. doi: 10.15294/jpii.v4i1

Baptiste, T. (2009). Overcoming prejudice: character education. Infobase Publishing. Chelsea House Publications, New York

Biasutti, M. (2013). Improvisation in dance education: teacher views. Research in Dance Education, 14(2), 120-140. doi: 10.1080/14647893.2012.761193

Boettcher, J. A. (1983). Dance Education Innovation through Technology. Journal of Physical Education, Recreation \& Dance, 54 (9), 40-40. doi: 10.1080/07303084.1983.10629598

Brown, A. K. (2014). A model for dance education: Promoting personal voice and communal learning. International Journal of Education through Art, 10(2), 179-188. doi: 10.1386/eta.10.2.179_1

Carr, D., \& Harrison, T. (2015). Educating character through stories. Andrews UK Limited. La Vergne, USA

Citra, Y. (2012). Pelaksanaan pendidikan karakter dalam pembelajaran [Implementation of character education in learning]. Jurnal IImiah Pendidikan Khusus, 1 (1), 237-249.

Cherng, H. Y. S., Hannum, E., LU, C., Kong, P. A., \& YU, X. (2019). China: Sociological Perspectives on Ethnicity and Education: Views from Chinese and English Literatures. In The Palgrave handbook of race and ethnic inequalities in education (pp. 301-344). Palgrave Macmillan, Cham. doi: 10.1007/978-3-319-94724-2_8 
Connell, J. (2009). Dance education: an examination of practitioners' perceptions in secondary schools and the necessity for teachers skilled in the pedagogy and content of dance. Research in Dance Education, 10(2), 115-130. https://doi.org/10.1080/14647890903019440

Creswell, J. W. (2014). A concise introduction to mixed methods research. SAGE publications, United States of America.

Cuellar-Moreno, M. (2016). Methodology and beliefs in primary school dance education. Journal of Physical Education and Sport, 16(3), 743-751. https://doi.org/10.7752/jpes.2016.03120

Cunningham, C. A. (2007). Character education in public schools: The quest for a suitable ontology. Annual Meeting of the American Educational Research Association (Moral Education SIG), Chicago, IL.

Dahliani, D. (2010). Local Wisdom In built Environment in Globalization Era. International Journal of Education and Research, 3(6). https://www.ijern.com/journal/2015/June2015/13.pdf

Damm, A. (2011). Mahatma Gandhi and Character Education in Non-Violence: Its Relevance in Religious Studies Today. Teaching Theology \& Religion, 14(1), 3-12. doi:10.1111/j.1467-9647.2010.00667.x

Demirel, M., Özmat, D., \& Elgün, I. Ö. (2016). Primary School Teachers' Perceptions about Character Education. Educational Research and Reviews, $11(17), 1622-1633$. DOI: 10.5897/ERR2016.2729

Dermawan, W., Purnama, C., \& Mahyudin, E. (2020). Penguatan "Kaulinan Barudak Sunda" sebagai permainan tradisional di Kecamatan Jatinangor [Strengthening "Kaulinan Barudak Sunda" as a traditional game in Jatinangor District]. Jurnal Pengabdian dan Pemberdayaan Masyarakat. 7(1), 1-15. https://doi.org/10.21831/jppm.v7i1.28798

Saepudin, Encang, \& Ninis A. Damayani,. (2016). Nilai-Nilai Budaya Sunda dalam Permainan [Sundanese Cultural Values in Games]. Jispo, 6(1-Januari-Juni), 1-22. DOI: 10.15575/jp.v6il.1745

Enyedy, N., \& Goldberg, J. (2004). Inquiry in interaction: How local adaptations of curricula shape classroom communities. Journal of Research in Science Teaching, 41 (9), 905935. https://doi.org/10.1002/tea.20031 
Dedi Rosala \& Agus Budiman, Local Wisdom-based Dance Learning: Teaching Characters...

Fadrusiana, E. G., \& Triastuti, R. (2020). The Roles of Jaga Sesama Social Community to Strengthen the Religion Character of Surakarta Society. 3rd International Conference on Learning Innovation and Quality Education (ICLIQE 2019), 1142-1148. Atlantis Press.

Fathorrahman, Z., \& Farida, S. (2018). Pembentukan Karakter Positif Peserta Didik Melalui Bimbingan Pribadi Sosial [Positive Character Formation of Students through Social Personal Guidance]. KABILAH: Journal of Social Community, 3(1), 115-129. https://doi.org/10.35127/kbl.v5i2

Gard, M. (2001). Aesthetics, athletics and art: A study of men who dance [Ph.D Thesis, University of Wollongong]. University of Wollongong Repository. https://ro.vow.edu.au/theses/1767/

Giguere, M. (2015). Dance education action research: a twin study. Research in Dance Education, 16(1), 16-32. https://doi.org/10.1080/14647893.2014.971231

Gilbert, A. G. (2005). Dance Education in the 21st Century: A Global Perspective. Journal of Physical Education, Recreation \& Dance, 76(5), 26-35. https://doi.org/10.1080/07303084.2005.10608250

Gloriani, Y. (2013). Kajian Nilai-Nilai Sosial Dan Budaya Pada Kakawihan Kaulinan Barudak Lembur Serta Implementasinya Dalam Pembelajaran Bahasa Dan Sastra Indonesia Berbasis Multikultural [Study of Social and Cultural Values in Kaulinan Barudak Lembur and Its Implementation in Multicultural-Based Learning of Indonesian Language and Literature]. Lokabasa, 4 (2). https://doi.org/10.17509/jlb.v4i2.3147

Hammond, L., \& Brandt, C. (2004). Science and cultural process: Defining an anthropological approach to science education. Studies in Science Education, 40(1), 1-47. doi:10.1080/03057260408560202

Hapsari, P. L. (2013). Character education values in reading section of e-English textbook for senior high school students grade XI. ELT Forum: Journal of English Language Teaching, 2(1). DOI: https://doi.org/10.15294/elt.v2i1

Hariyanto, S. M. (2012). Pendidikan Karakter [Character Education]. Bandung: PT. Remaja Rosdakarya.

Hasanah, A., Gustini, N., \& Rohaniawati, D. (2016). Cultivating character education based on Sundanese culture local wisdom. Jurnal Pendidikan Islam, 2(2), 231-253. doi: :10.15575/jpi.v2i2.788. 
Hedegaard-Soerensen, L., \& Penthin., S. (2020). Student-teacher dialogue for lesson planning: inclusion in the context of national policy and local culture. Nordic Journal of Studies in Educational Policy, 6(1), 25-36. https://doi.org/10.1080/20020317.2020.1747376

Hidayah, N., \& Ramli, M. (2017). Need of Cognitive-Behavior Counseling Model Based on Local Wisdom to Improve Meaning of Life of Madurese Culture Junior High School Students. 3rd International Conference on Education and Training (ICET 2017). Atlantis Press. 301-307, https://doi.org/10.2991/icet-17.2017.53

Hilman, I., \& Hendriawan, N. (2018). Local Wisdom of Indigenous Community of Kampung Dukuh as Culture Preservation in Ciroyom Village, Cikelet District, Garut Regency, West Java Province. IOP Conference Series: Earth and Environmental Science, 145(1), 13151755. doi :10.1088/1755-1315/145/1/012028

Ho, W.-C. (2006). The Politics of Implementing Local Cultures in Music Education in Taiwan. Research and Issues in Music Education, 4(1), 1-14. https://commons.lib.jmu.edu/rime/vol4/iss 1/4

Ho, W.-C. (2016). National identity in the Taiwanese system of music education. In Patriotism and Nationalism in Music Education (pp. 59-76). Routledge. DOI: 10.25071/17086701.37763

Hongcheng, S., \& Minhui, Q. (2010). The other in education: The distance between school education and local culture. Chinese Education \& Society, 43(5), 47-61. https://doi.org/10.2753/CED1061-1932430503

Ilhami, A., Riandi, R., \& Sriyati, S. (2019). Implementation of science learning with local wisdom approach toward environmental literacy. Journal of Physics: Conference Series, 1157(2), 22030. doi:10.1088/1742-6596/1157/2/022030

Kamilia, H. R., \& Hermawan, L. (2019). Pengaruh Implementasi Model Pembelajaran SAVI Terhadap Kreativitas Peserta Didik Dalam Tari Kaulinan Barudak di Sekolah Dasar [The Effect of the Implementation of SAVI Learning Model on the Creativity of Students in the Kaulinan Barudak Dance in Elementary Schools]. 17(1), 1-6. . EDUCARE, 17(1), 1-6. Retrieved from http://jurnal.fkip.unla.ac.id/index.php/educare/article/view/234

Kartikawangi, D. (2017). Symbolic convergence of local wisdom in cross-cultural collaborative social responsibility: Indonesian case. Public Relations Review, 43(1), 3545. https://doi.org/10.1016/j.pubrev.2016.10.012

Koff, S. R. (2000). Toward a Definition of Dance Education. Childhood Education, 77(1), 27-32. https://doi.org/10.1080/00094056.2000.10522134 
Dedi Rosala \& Agus Budiman, Local Wisdom-based Dance Learning: Teaching Characters...

Komariah, S., \& Asyahidda, F. N. (2019a). Counter Enculturation: A Revitalization Strategy to Strengthen Local Wisdom in Fast Changing Age. 1st International Conference on Innovation in Education (IColE 2018). Atlantis Press.

Komariah, S., \& Asyahidda, F. N. (2019b). Local Wisdom as Educational Tourism: A Study from Kampong Dukuh West Java Indonesia. 3rd International Seminar on Tourism (ISOT 2018). Atlantis Press. 282-286, https://doi.org/10.2991/icoie-18.2019.63

Komariah, S., \& Asyahidda, F. N. (2019c). Will local wisdom still exist in globalization? A study of social justice for the community with local wisdom. Research for Social Justice: Proceedings of the International Seminar on Research for Social Justice (ISRISJ 2018), October 30, 2018, Bandung, Indonesia, 92. Routledge. 9296.https:doi.org/10.1201/9780429428470

Kristanto, M. (2014). Pemanfaatan Cerita Rakyat Sebagai Penanaman Etika Untuk Membentuk Pendidikan Karakter Bangsa [Utilization of Folklore as Inculcation of Ethics to Form National Character Education]. Mimbar Sekolah Dasar, 1(1), 59-64. https://doi.org/10.17509/mimbar-sd.v1i1.864

Lapsley, D. K., \& Power, F. (2005). Character psychology and character education. University of Notre Dame Press. American Psychological Association, Washington,

Larson, R. J. (2004). An analysis of state-approved curricula in character education. Northern Illinois University, DeKalb, Illinois.

Lestari, A. T. (2017). Pembelajaran Tari Kreatif Melalui Kaulinan Budak Lembur di Sekolah Dasar [Learning Creative Dance through Overtime Slave Cultures in Elementary Schools]. NATURALISTIC: Jurnal Kajian Penelitian Pendidikan Dan Pembelajaran, 1 (2), 102-111. https://doi.org/10.35568/naturalistic.v1i2.3

Lo, L.-I. (2014). Music education reform in Taiwan: beginning music teachers' perceptions of their teacher preparation at National Taiwan Normal University. Boston University. Boston, Massachusetts .

Maarif, M. A. (2018). Analisis Strategi Pendidikan Karakter Melalui Hukuman Preventif [Analysis of Character Education Strategies through Preventive Punishment]. Ta'allum: Jurnal Pendidikan Islam, 6(1), 31-56. https://doi.org/10.21274/taalum.2018.6.1.31-56

Margaret, N. H. (1985). Doubler,. Dance A Creative Art Experience. University of Wisconsin Press : Madison, Wisconsin, United States.

Marvasti, A. (2004). Qualitative research in sociology. London : SAGE. 
McMillan, J. H., \& Schumacher, S. (2010). Research in Education: Evidence-Based Inquiry, MyEducationLab Series. Pearson. New Jersey: Pearson Education.

Megawangi, R. (2004). Pendidikan karakter [Character Education]. Jakarta: Indonesia Heritage Foundation.

Mubiar, M., Mamat, N. Bin, \& Syaodih, E. (2020). Exploring "Kaulinan Barudak" to Develop Children's Character Values in Islamic Early Childhood Education. Jurnal Pendidikan Islam, 6(1), 13-26. DOI: 10.15575/jpi.v6i1.8226

Mulyati, E., \& Hendriyana, H. (2013). Kaulinan Barudak sebagai Sumber Penciptaan Tari Anakanak di Kabupaten Sumedang [Kaulinan Barudak as a Source of Children's Dance Creation in Sumedang Regency]. Panggung, 23(3). http://dx.doi.org/10.26742/panggung.v23i3.146.g146

Mungmachon, M. R. (2012). Knowledge and Local Wisdom: Community treasure. International Journal of Humanities and Social Science, 2(13), 174-181. http://dx.doi.org/10.7575/aiac.ijalel.v.7n.2p.9 10

Murgianto, S. (1983). Pengetahuan Dasar Komposisi Tari [Basic Knowledge of Dance Composition]. Jakarta: (Direktorat Jendral) Pendidikan Dasar dan Menengah Departemen Pendidikan dan Kebudayaan. [Basic Knowledge of Dance Composition].

Murwaningsih, T., Fadhilah, S. S., \& Sholeh, A. R. (2020). The Implementation of Characters' Values Through Local Wisdom of Sadranan in Elementary Schools. International Journal of Multicultural and Multireligious Understanding, 7(1), 450-458. http://dx.doi.org/10.18415/ijmmu.v7i1.1315

Narvaez, D., Lapsley, D. K., Hagele, S., \& Lasky, B. (2006). Moral chronicity and social information processing: Tests of a social cognitive approach to the moral personality. Journal of Research in Personality, 40(6), 966-985. https://doi.org/10.1016/j.jp.2005.10.003

Niemiec, R. M. (2017). Character strengths interventions: A field guide for practitioners. Hogrefe Publishing. Boston, Massachusetts

Politis, G. (1990). Computers and Dance: A Bibliography. Leonardo, 23(1), 87. https://doi.org/10.2307/1578471

Pratiwi, G. T. O. D. (2015). Kaulinan Budak Sebagai Bahan Ajar Untuk Menstimulus Minat Tari Siswa di SD Labschool UPI Bandung: Studi Eksperimen Melalui Pembelajaran Kaulinan Budak Oray-Orayan [Kaulinan Budak as Teaching Material to Stimulate Students' 
Dedi Rosala \& Agus Budiman, Local Wisdom-based Dance Learning: Teaching Characters...

Dance Interest in SD Labschool UPI Bandung: Experimental Study through Oray-Orayan Kaulinan Learning]. Universitas Pendidikan Indonesia. http://repository.upi.edu/id/eprint/18013

Puspita, F. (2015). Pembentukan karakter berbasis pembiasaan dan keteladanan [Character building based on habituation and exemplary]. Thesis. UIN Sunan Kalijaga, Yogyakarta.

Saepudin, E. \& Damayani, N. A. (2016). Nilai-Nilai Budaya Sunda dalam Permainan [Sundanese Cultural Values in Games]. Jispo, 6(1-Januari-Juni), 1-22. 10.15575/jp.v6i1.1745

Sari, D. N., \& Utami, R. D. (2016). Implementasi Pendidikan Karakter Melalui Pembiasaan Menyanyikan Lagu Wajib Nasional Pada Siswa Kelas Atas di SDN 21 Surakarta [Implementation of Character Education through the Habit of Singing National Compulsory Songs for Upper Class Students at SDN 21 Surakarta].. Undergraduate thesis, Universitas Muhammadiyah Surakarta. http://eprints.ums.ac.id/id/eprint/42677

Sari, D. P. (2016). Peranan Lagu Nasional Dalam Pembentukan Nilai Karakter Siswa Kelas IV Sekolah Dasar Negeri di Kecamatan Tugu Kota Semarang [The Role of National Song in Forming Character Values of Class IV Elementary School Students in Tugu District, Semarang City]. (Doctoral dissertation, Universitas Negeri Semarang).

Sherman, R. R., \& Webb, R. B. (2018). Qualitative research in education: Focus and methods (Vol. 3). England: Psychology Press

Silkyanti, F. (2019). Analisis Peran Budaya Sekolah yang Religius dalam Pembentukan Karakter Siswa. Indonesian Values and Character Education Journal, 2(1), 36-42. http://dx.doi.org/10.23887/ivcej.v2i1.17941

Sööt, A., \& Viskus, E. (2014). Contemporary Approaches to Dance Pedagogy - The Challenges of the 21st Century. Procedia - Social and Behavioral Sciences, 112 (Iceepsy 2013), 290-299. https://doi.org/10.1016/j.sbspro.2014.01.1167

Sopa, M. (2018). Local wisdom in the cultural symbol of Indonesian traditional house. KnE Social Sciences, 524-531. https://doi.org/10.18502/kss.v3i4.1962 (

Suarmika, P. E., \& Syarifah, M. (2019). Ethnopedagogical Study: Educational Values Depicted in Tumpek Wariga. KnE Social Sciences, 555-563. https://doi.org/10.18502/kss.v3i10.3946

Suastra, I. W., Jatmiko, B., Ristiati, N. P., \& Yasmini, L. P. B. (2017). Developing characters based on local wisdom of Bali in teaching physics in senior high school. Jurnal Pendidikan IPA Indonesia, 6(2), 306-312. https://doi.org/10.15294/jpii.v6i2 
Sugiyo, R., \& Purwastuti, L. A. (2017). Local wisdom-based character education model in elementary school in Bantul Yogyakarta Indonesia. Sino-US English Teaching, 14(5), $299-$ 308. doi:10.17265/1539-8072/2017.05.003

Sukendar, A., Usman, H., \& Jabar, C. S. A. (2019). Teaching-loving-caring (asah-asih-asuh) and semi-military education on character education management. Jurnal Cakrawala Pendidikan, 38(2), 292-304. https://doi.org/10.21831/cp.v38i2.24452

Sunaengsih, C. (2015). Pengaruh Model Pembelajaran Transdisciplinary Terhadap Karakter Siswa Pada Sekolah Dasar Internasional Berbasis International Baccalaureate [The Effect of Transdisciplinary Learning Model on Student Character in International Baccalaureate-Based International Schools]. Mimbar Sekolah Dasar, 2(2), 167-174. https://doi.org/10.17509/mimbar-sd.v2i2.1327

Sungkharat, U., Doungchan, P., Tongchiou, C., \& Tinpang-nga, B. (2010). Local wisdom: the development of community culture and production processes in Thailand. International Business \& Economics Research Journal (IBER), 9(11). https://doi.org/10.19030/iber.v9i1 1.37

Suryana, S. (2013). Character Education Model in Early Age Children. Indonesian Journal of Early Childhood Education Studies, 2(1). https://doi.org/10.15294/ijeces.v2i 1

Thornberg, R. (2010). A student in distress: Moral frames and bystander behavior in school. The Elementary School Journal, $110(4), 585-608$. https://doi.org/10.19030/iber.v9i1 1

Tresnawati, N. (2018). Pembelajaran sains berbasis kearifan lokal dalam upaya peningkatan konservasi lingkungan pada mahasiswa PGSD di batik tulis Ciwaringin Cirebon [Learning science based on local wisdom in an effort to increase environmental conservation in PGSD students in Ciwaringin Cirebon written batik]. Al Ibtida: Jurnal Pendidikan Guru MI, 5(1), 69-82. http://dx.doi.org/10.24235/al.ibtida.snj.v5i1.2603

van Oord, L. (2013). Moral education and the International Baccalaureate learner profile. Educational Studies, 39(2), 208-218. https://doi.org/10.1080/03055698.2012.717260

Widesma, A. V., \& Adnan, M. F. (2019). The Role of Local Wisdom Values In The Implementation of the Development of Nagari Kamang Mudiak, Agam District, West Sumatera. JISPO Jurnal IImu Sosial Dan IImu Politik, 9(2), 249-255. 10.15575/jispo.v9i2.5383 